\title{
Rheinheimera chironomi sp. nov., isolated from a chironomid (Diptera; Chironomidae) egg mass
}

Correspondence
Malka Halpern
mhalpern@research.haifa.ac.il

\author{
Malka Halpern, ${ }^{1}$ Yigal Senderovich ${ }^{1}$ and Sagi Snir ${ }^{2}$ \\ 'Department of Biology, Faculty of Science and Science Education, University of Haifa, Oranim, \\ Tivon 36006, Israel \\ ${ }^{2}$ Institute of Evolution, University of Haifa, Mount Carmel, Haifa 31905, Israel
}

The genus Rheinheimera was created by Brettar et al. (2002) while screening blue-coloured bacterial isolates from different depth stations in the central Baltic Sea. At present, the genus comprises three species: Rheinheimera baltica (Brettar et al., 2002), Rheinheimera pacifica (Romanenko et al., 2003) and Rheinheimera perlucida (Brettar et al., 2006). All three species were isolated from marine environments. In this study, a new member of the genus Rheinheimera that was isolated from a freshwater insect egg mass is proposed on the basis of polyphasic studies.

Strain $\mathrm{K} 19414^{\mathrm{T}}$ was isolated from a chironomid (nonbiting midge) egg mass while the diversity of the culturable bacteria in chironomid egg masses was under study (Halpern et al., 2007). Chironomid egg masses were sampled in September 2004, as described previously (Halpern et al., 2007). Egg masses were washed thoroughly with sterile saline water and then their homogenates were diluted and cultured directly on bacteriological media (Halpern et al., 2007). Strain K19414 ${ }^{\mathrm{T}}$ was isolated from an egg mass that was sampled from Kishon River in northern Israel, cultured on LB agar and incubated at $30{ }^{\circ} \mathrm{C}$ for $48 \mathrm{~h}$ in the dark. Another isolate from the above-described

Abbreviations: ML, maximum likelihood; MP, maximum parsimony; NJ, neighbour joining.

The GenBank/EMBL/DDBJ accession number for the 16S rRNA gene sequence of strain $\mathrm{K} 19414^{\top}$ is $\mathrm{DQ} 298025$.

An electron micrograph of cells of strain $\mathrm{K} 19414^{\top}$ and details of its fatty acid profile in comparison with those of related type strains are available as supplementary material with the online version of this paper. study was recently characterized as the type strain of Oceanobacillus chironomi (Raats \& Halpern, 2007).

Strain $\mathrm{K} 19414^{\mathrm{T}}$ is a motile Gram-negative rod, psychrotolerant and strictly aerobic. Its exact taxonomic position was determined by means of a polyphasic approach that included phenotypic properties and phylogenetic analysis based on the 16S rRNA gene sequence.

For electron microscopy, bacteria in LB agar medium were suspended in saline. The samples were adhered to a carboncoated grid and stained with $2 \%$ uranyl acetate and photographed under a JEM-1200EX electron microscope (JEOL). Electron microscopy showed that the cells were rods with a polar flagellum $(0.3-0.7 \times 1.0-2.4 \mu \mathrm{m})$ (Supplementary Fig. S1 in IJSEM Online).

The 16S rRNA gene was analysed to determine its phylogenetic position. Universal bacterial primers $8 \mathrm{f}$ and $1512 \mathrm{r}$ (Felske et al., 1997) were used to amplify internal fragments of the 16S rRNA gene. The amplified PCR product was purified with the Wizard PCR product purification kit (Promega). Purified PCR products were sequenced with primers $8 \mathrm{f}, 534 \mathrm{r}, 968 \mathrm{f}$ and $1512 \mathrm{r}$ as described in detail by Raats \& Halpern (2007). This resulted in a sequence of 1499 bp.

For identification of closest relatives, the 16S rRNA gene of strain $\mathrm{K} 19414^{\mathrm{T}}$ was compared with those of previously reported strains available in EMBL (http://www.ebi.ac.uk/). Using the BLAST program (version 2.0), the closest sequences obtained were those of R. baltica OS140 (96.9\%), 
R. baltica OSBAC5 (96.7\%), R. pacifica KMM $1406^{\mathrm{T}}$ $(96.5 \%)$, R. perlucida BA131 ${ }^{\mathrm{T}}(96.0 \%)$, R. baltica OSBAC1 ${ }^{\mathrm{T}}$ (95.8\%), Alishewanella fetalis CCUG $30811^{\mathrm{T}}(95.8 \%)$, Brenneria salicis DSM $30166^{\mathrm{T}}(91.5 \%)$ and Colwellia piezophila $\mathrm{Y}_{223 \mathrm{G}^{\mathrm{T}}}(89.0 \%)$. The sequences were aligned by the multiple alignment package CLUSTAL w. Phylogenetic trees were generated by neighbour joining (NJ), maximum parsimony (MP) and maximum likelihood (ML). NJ and MP trees were obtained using the MEGA software package (Kumar et al., 2004), while ML was computed by PHYLIP (Felsenstein, 1993). For NJ, distance correction was performed using the Kimura two-parameter model (K2ST) using rate variation across sites. The bootstrap values obtained were from 1000 iterations. The NJ tree was drawn by the MEGA software (Fig. 1). In contrast to the highest sequence similarity to $R$. baltica OS140 as found by BLAST, all phylogenetic inference methods located the novel strain as a sibling to $R$. pacifica KMM $1406^{\mathrm{T}}$.

For phenotypic characterization, LB agar was used as the basal medium with a final concentration of $0.5 \% \mathrm{NaCl}$. Salt tolerance was determined in LB agar containing varying concentrations of $\mathrm{NaCl}$ at $37{ }^{\circ} \mathrm{C}$. Growth at various temperatures $(4,6,8,10,15,18,25,30,32,35,37,39,40,41$ and $43{ }^{\circ} \mathrm{C}$ ) was measured on LB agar. Growth under anaerobic conditions was determined after incubation in an anaerobic chamber on LB agar supplemented with glucose or nitrate. Strain K19414 ${ }^{\mathrm{T}}$ had optimal growth between 0.5 and $1 \% \mathrm{NaCl}$ and at $30-37^{\circ} \mathrm{C}$ (Table 1 ).

Biochemical tests were performed by means of API 20E, API 20NE and API ZYM identification systems (bioMérieux) at $37^{\circ} \mathrm{C}$. Carbon assimilation was analysed using Biolog GN microwell plates according to the manufacturer's instructions (release 3.50, version DE; Biolog). The plates were incubated for $48 \mathrm{~h}$ at $37^{\circ} \mathrm{C}$. Wells that changed to purple were marked as positive for metabolic activity. Sensitivity of the strain to antibiotics was tested by means of LB agar and Sensi-discs (BBL). Tests were incubated for $48 \mathrm{~h}$.

For the cellular fatty acid analysis, cells were cultured on a tryptic soy agar (Difco) at $28{ }^{\circ} \mathrm{C}$ for $24 \mathrm{~h}$ and then the fatty acids were extracted. The fatty acid profile was analysed by means of the MIDI/Hewlett Packard Microbial Identification system (Analytical Services Inc.), which uses GC profiles of fatty acid methyl esters. The major fatty acid components (exceeding $10 \%$ ) of strain $\mathrm{K} 19414^{\mathrm{T}}$ are $16: 0$ $(14.80 \%)$ and summed feature $3(16: 1 \omega 7 c$ and/or $15: 0$ iso 2-OH; 25.76\%) (Supplementary Table S1).

For determination of the DNA G $+\mathrm{C}$ content, genomic DNA of strain $\mathrm{K}_{19414^{\mathrm{T}}}$ was prepared according to a modification of the procedure of Wilson (1987). The DNA $\mathrm{G}+\mathrm{C}$ content was determined using HPLC analysis of hydrolysed DNA according to Mesbah et al. (1989). The analysis was performed by the BCCM/LMG Bacteria Collection Identification Service (Laboratory of Microbiology, Ghent University, Belgium). The G + C content of strain $\mathrm{K} 19414^{\mathrm{T}}$ was 49.9 mol\%.

The morphological, physiological and biochemical traits of strain $\mathrm{K} 19414^{\mathrm{T}}$ are summarized in the species description and in Table 1. API ZYM tests of strain K19414 ${ }^{\mathrm{T}}$ revealed a broad set of 12 enzyme activities (Table 1). Phylogenetic relationships between strain $\mathrm{K} 19414^{\mathrm{T}}$ and some related taxa are shown in Fig. 1. Comparative 16S rRNA gene sequence analysis showed that the new isolate was phylogenetically most closely related to Rheinheimera species, with $95.8-96.5 \%$ sequence similarity to the type strains. The new isolate shared its main characteristics with Rheinheimera species, such as being aerobic and oxidasepositive, motile rods by means of polar flagella, assimilating $\mathrm{N}$-acetylglucosamine and hydrolysing gelatin. Its DNA $G+C$ content was close to those of the other described Rheinheimera species (48.9-49.9 mol\%) (Table 1). Unsaturated fatty acids formed a major fraction of the total fatty acids in strain K19414 ${ }^{\mathrm{T}}$, as in the other described strains of the genus Rheinheimera (Supplementary Table S1). Together with the findings mentioned above, strain K19414 ${ }^{\mathrm{T}}$ showed significant characteristics that allowed clear differentiation from all three described Rheinheimera species. It lacked catalase activity, grew at relatively low $\mathrm{NaCl}$ concentrations $(0-2 \%)$, grew at $40{ }^{\circ} \mathrm{C}$, which is the highest growth temperature described for species of this genus, and was positive for malate assimilation and for valine arylamidase, cystine arylamidase and $\alpha$-mannosidase (Table 1). On the basis of phenotypic characterization and phylogenetic analysis (Stackebrandt \& Goebel, 1994), we propose that strain $\mathrm{K} 19414^{\mathrm{T}}$ should be classified as the type strain of a novel species, Rheinheimera chironomi sp. nov.

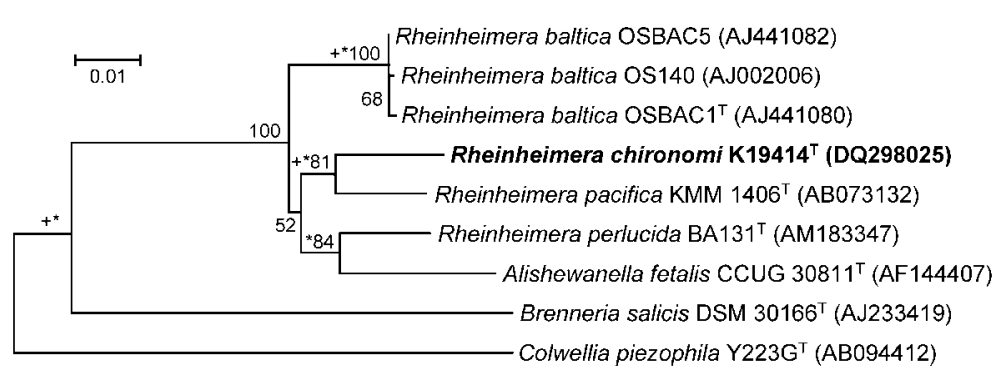

Fig. 1. Unrooted NJ tree (MEGA3, based on alignment from CLUSTAL W) of strain K19414 ${ }^{\top}$ and its closest relatives from the genus Rheinheimera and related taxa based on $16 S$ rRNA gene sequences. Bootstrap values are indicated along branches. Branches found by ML with $P$ values $<0.01$ are marked by an asterisk. Branches marked by a plus sign are in consensus among all reconstruction methods. Bar, 0.01 accumulated changes per nucleotide position. 
Table 1. Differential properties of strain $\mathrm{K} 19414^{\top}$ and Rheinheimera type strains

Strains: 1, strain $\mathrm{K}_{19414^{\mathrm{T}}}$; 2, R. perlucida BA131 ${ }^{\mathrm{T}}$ (data from Brettar et al., 2006); 3, R. baltica OSBAC1 ${ }^{\mathrm{T}}$ (Brettar et al., 2002); 4, R. pacifica KMM $1406^{\mathrm{T}}$ (Romanenko et al., 2003). +, Positive; w, weakly positive; - , negative; ND, no data available.

\begin{tabular}{|c|c|c|c|c|}
\hline Feature & 1 & 2 & 3 & 4 \\
\hline \multicolumn{5}{|l|}{ Cell size $(\mu \mathrm{m})$} \\
\hline Width & $0.3-0.7$ & $0.6-1.2$ & $0.4-1.5$ & $0.6-0.8$ \\
\hline Length & $1.0-2.4$ & $0.9-2.4$ & $0.9-4.5$ & $1.8-2.0$ \\
\hline Flagellar arrangement & Polar & Polar & Polar & Bipolar, lateral \\
\hline Pigmentation & No pigment & No pigment & Blue & No pigment \\
\hline DNA $\mathrm{G}+\mathrm{C}$ content $(\mathrm{mol} \%)$ & 49.9 & 48.9 & 48.9 & 49.6 \\
\hline Catalase & - & + & + & + \\
\hline Hydrolysis of DNA & - & ND & ND & + \\
\hline Reduction of nitrate to nitrite & + & + & - & - \\
\hline \multicolumn{5}{|l|}{$\mathrm{NaCl}$ concentration for growth (\%) } \\
\hline Range & $0-2$ & $0-8$ & $0-3^{*}$ & $0-8$ \\
\hline Optimum & $0.5-1$ & $1-3$ & $1-3$ & ND \\
\hline \multicolumn{5}{|l|}{ Temperature for growth $\left({ }^{\circ} \mathrm{C}\right)$} \\
\hline Range & $4-40$ & $4-37$ & $4-30$ & $4-37$ \\
\hline Optimum & $30-37$ & $20-30$ & $20-25$ & ND \\
\hline \multicolumn{5}{|l|}{ Enzyme activities } \\
\hline Esterase (C4) & + & + & - & + \\
\hline Chymotrypsin & + & + & - & + \\
\hline Acid phosphatase & + & + & - & - \\
\hline$N$-Acetyl- $\beta$-glucosaminidase & + & + & - & + \\
\hline Valine arylamidase & $\mathrm{W}$ & - & - & - \\
\hline Cystine arylamidase & $\mathrm{W}$ & - & - & - \\
\hline$\alpha$-Mannosidase & + & - & - & - \\
\hline Acid production from glucose & - & - & + & - \\
\hline \multicolumn{5}{|l|}{ Assimilation of: } \\
\hline Arabinose, citrate & - & - & - & + \\
\hline Glucose & + & - & + & - \\
\hline Maltose & + & - & + & + \\
\hline Malate & + & ND & - & - \\
\hline \multicolumn{5}{|l|}{ Utilization of: } \\
\hline$\alpha$-Cyclodextrin & - & W & - & ND \\
\hline Tween 40 & + & - & + & ND \\
\hline Tween 80 & + & - & - & ND \\
\hline$\beta$-Hydroxybutyric acid & - & + & - & ND \\
\hline p-Hydroxyphenylacetic acid & - & - & + & ND \\
\hline L-Alanine & - & + & - & $\mathrm{ND}$ \\
\hline L-Alanyl glycine, L-threonine & - & w & - & ND \\
\hline Glucose, maltose, sucrose & $\mathrm{W}$ & - & - & ND \\
\hline Asparagine, arginine, lysine & - & - & - & + \\
\hline $\begin{array}{l}\text { Pyruvic acid methyl ester, succinic acid } \\
\text { monomethyl ester, succinic acid, glycyl } \\
\text { L-glutamic acid }\end{array}$ & + & - & ND & $\mathrm{ND}$ \\
\hline Glycyl L-aspartic acid & $\mathrm{W}$ & - & ND & ND \\
\hline Acetic acid, glycerol & - & - & - & + \\
\hline
\end{tabular}

${ }^{\star} R$. baltica OS550 grew in the presence of $6 \% \mathrm{NaCl}$ (Brettar et al., 2002). 


\section{Description of Rheinheimera chironomi sp. nov.}

Rheinheimera chironomi [chi.ro' no.mi. N.L. gen. n. chironomi of Chironomus, named after the non-biting midge insect from the genus Chironomus (Diptera; Chironomidae) from which the type strain was isolated].

Cells are aerobic, Gram-negative, non-pigmented rods, $1.0-2.4 \mu \mathrm{m}$ long and $0.3-0.7 \mu \mathrm{m}$ wide, occurring as single cells or in pairs, and they are motile by means of a single polar flagellum. Colonies are circular, non-pigmented, smooth and convex. Oxidase-positive, catalase-negative and able to reduce nitrate to nitrite. Sodium ions are not required for growth. Growth is observed in $0-2 \%(\mathrm{w} / \mathrm{v})$ $\mathrm{NaCl}$, but not in $3 \% \mathrm{NaCl}$. Grows at $4-40{ }^{\circ} \mathrm{C}$, but not at $41{ }^{\circ} \mathrm{C}$. Hydrolyses gelatin and casein but not DNA. Grows on LB and half-strength marine agar. Does not haemolyse bovine blood and does not grow on MacConkey agar. The major measurable fatty acid components (exceeding $5 \%$ ) of the type strain are $11: 03-\mathrm{OH}(5.53 \%), 12: 03-\mathrm{OH}$ $(8.54 \%) 15: 0(6.86 \%), 16: 0(14.80 \%)$, summed feature 3 (16: $1 \omega 7 c$ and/or $15: 0$ iso $2-\mathrm{OH} ; 25.76 \%), 17: 0$ (5.76\%), $17: 1 \omega 8 c(7.56 \%)$ and $18: 1 \omega 7 c(6.68 \%)$. The following fatty acids are detected in the type strain as minor components: 9:0 (0.2\%), 10:0 (1.2\%), 11:0 (1.35\%), $10: 03-\mathrm{OH}(0.53 \%)$, unknown ECL $11.799(2.63 \%), 12: 0$ $(1.06 \%), 13: 0(0.62 \%), 12: 0$ iso $3-\mathrm{OH}(0.41 \%), 14: 0$ iso $(0.19 \%), 14: 0(0.89 \%)$, summed feature 1 (one or more of 13:0 3-OH, $15: 1$ iso I and $15: 1$ iso $\mathrm{H} ; 1.9 \%), 15: 0$ anteiso $(0.28 \%), 15: 1 \omega 8 c(2.75 \%), 15: 1 \omega 6 c(1.04 \%)$, summed feature $2(14: 03-\mathrm{OH}$ and/or $16: 1$ iso I; $0.28 \%)$, $16: 0$ iso $(1.45 \%), 17: 0$ iso $(0.19 \%), 17: 0$ anteiso $(0.41 \%), 17: 1 \omega 6 c(0.87 \%)$ and $18: 0(0.25 \%)$. Cells are resistant to neomycin, penicillin $G$ and bacitracin but susceptible to tetracycline, ampicillin, vancomycin, streptomycin, chloramphenicol, novobiocin and SXT (sulfamethoxazole and trimethoprim). In the API 20NE test system, nitrate is reduced to nitrite, glucose, $\mathrm{N}$-acetylglucosamine, maltose and malate are assimilated and enzyme activities of protease (gelatinase) and $\beta$-galactosidase are detected. In the API ZYM test system, 12 enzyme activities are detected: alkaline and acid phosphatases, esterase ( $\mathrm{C} 4$ and $\mathrm{C} 8$ ), leucine arylamidase, valine arylamidase, cystine arylamidase, trypsin, $\alpha$-chymotrypsin, naphthol-AS-BI-phosphohydrolase, $N$ acetyl- $\beta$-glucosaminidase and $\alpha$-mannosidase. In the Biolog GN2 test system, Tweens 40 and 80, D-galactose, D-glucose, maltose, sucrose, pyruvic acid methyl ester, succinic acid monomethyl ester, L-alanine, L-alanyl glycine, glycyl Laspartic acid and glycyl L-glutamic acid are utilized as substrates; all other Biolog GN2 substrates are not utilized. The $\mathrm{G}+\mathrm{C}$ content of the type strain is $49.9 \mathrm{~mol} \%$.

The type strain is strain $\mathrm{K} 19414^{\mathrm{T}}\left(=\mathrm{DSM} 18694^{\mathrm{T}}=\mathrm{LMG}\right.$ $23818^{\mathrm{T}}$ ), which is of freshwater origin.

\section{References}

Brettar, I., Christen, R. \& Höfle, M. G. (2002). Rheinheimera baltica gen. nov., sp. nov., a blue-coloured bacterium isolated from the central Baltic Sea. Int J Syst Evol Microbiol 52, 1851-1857.

Brettar, I., Christen, R. \& Höfle, M. G. (2006). Rheinheimera perlucida sp. nov., a marine bacterium of the Gammaproteobacteria isolated from surface water of the central Baltic Sea. Int J Syst Evol Microbiol 56, 2177-2183.

Felsenstein, J. (1993). PHYLIP (phylogeny inference package), version 3.5c. Distributed by the author. Department of Genome Sciences, University of Washington, Seattle, USA.

Felske, A., Rheims, H., Wolterink, A., Stackebrandt, E. \& Akkermans, A. D. L. (1997). Ribosome analysis reveals prominent activity of an uncultured member of the class Actinobacteria in grassland soils. Microbiology 143, 2983-2989.

Halpern, M., Landsberg, O., Raats, D. \& Rosenberg, E. (2007). Culturable and VBNC Vibrio cholerae: interactions with chironomid egg masses and their bacterial population. Microb Ecol 53, 285-293.

Kumar, S., Tamura, K. \& Nei, M. (2004). MEGA3: integrated software for molecular evolutionary genetics analysis and sequence alignment. Brief Bioinform 5, 150-163.

Mesbah, M., Premachandran, U. \& Whitman, W. B. (1989). Precise measurement of the $\mathrm{G}+\mathrm{C}$ content of deoxyribonucleic acid by highperformance liquid chromatography. Int J Syst Bacteriol 39, 159-167.

Raats, D. \& Halpern, M. (2007). Oceanobacillus chironomi sp. nov., a halotolerant and facultatively alkaliphilic species isolated from a chironomid egg mass. Int J Syst Evol Microbiol 57, 255-259.

Romanenko, L. A., Uchino, M., Falsen, E., Zhukova, N. V., Mikhailov, V. V. \& Uchimura, T. (2003). Rheinheimera pacifica sp. nov., a novel halotolerant bacterium isolated from deep sea water of the Pacific. Int J Syst Evol Microbiol 53, 1973-1977.

Stackebrandt, E. \& Goebel, B. M. (1994). Taxonomic note: a place for DNA-DNA reassociation and $16 \mathrm{~S}$ rRNA sequence analysis in the present species definition in bacteriology. Int J Syst Bacteriol 44, 846-849.

Wilson, K. (1987). Preparation of genomic DNA from bacteria. In Current Protocols in Molecular Biology, pp. 2.4.1-2.4.5. Edited by F. M. Ausubel, R. Brent, R. E. Kingston, D. D. Moore, J. A. Smith \& K. Struhl. New York: Greene Publishing and Wiley-Interscience. 